\title{
DISKURSUS PERKAWINAN BEDA AGAMA DI INDONESIA DALAM TINJAUAN UNIVERSALISME HAM DAN RELATIVISME BUDAYA
}

\author{
Fitrawati \\ Institut Agama Islam Negeri Bukittinggi \\ e-mail: fitraw036@gmail.com \\ \begin{tabular}{l|l|l|} 
Submit: 30-01-2021 & Direvisi: 26-03-2021, & Dipublish: 21-06-2021
\end{tabular} \\ 06-04-2021
}

\begin{abstract}
This paper tries to examine the right to freedom of interfaith marriage in Indonesia from the perspective of Human Rights Universalism and Cultural Relativism. The purpose of this paper is to explain how universalism and cultural relativity view interfaith marriage in Indonesia. This research is a normative legal research. This study uses a literature approach. The findings of this study indicate that interfaith marriage in Indonesia is still not well accepted and has always been controversial news in the community, even considered to have exceeded or violated the provisions of marriage, but there are still followers of different religions who decide to marry. In fact, many of them are smuggling laws so that their marriages are recognized by the state, namely by registering marriages abroad and then continuing the registration in Indonesia. Meanwhile, on the other hand, Indonesia already has a law on Marriage, namely, Article 2 paragraph 1. It is also contained in the article of the Universal Declaration of Human Rights, namely the right to freedom of marriage (article 16 UDHR) which includes the right to marry between religions (different religions), and the right to freedom of religion (article $18 \mathrm{UDHR}$ ) which includes the right to change religions. Meanwbile, in cultural realivism, it rejects everything that is universal.
\end{abstract}

Kata kunci: Universalism, Cultural Relativism, Marriage with Different Religiuos.

PENDAHULUAN

$\mathcal{M}_{\text {sangat }}^{\text {asalah HAM menjadi hal }} \underset{\text { penting }}{\text { untuk }}$ diperbincangkan apalagi mengenai perselisihan dua ide yang menerapkan HAM dengan cakupan yang cukup luas yaitu, antara universalisme dengan relativisme budaya. Diamana perdebatan antara dua ideologi ini berimplikasi kepada sebuah perpecahan dalam kehidupan masyarakat diberbagai wilayah, seperti yang terjadi di Barat, dimana mayoritasnya menganut paham universalisme dalam menerapkan hukum, sedangkan negara-negara Timur lebih memilih relativisme budaya ((cultural relativism). Hal ini terjadi karena perbedaan konsep dan makna HAM itu sendiri. (Jaya, 2017: 56)
Banyaknya pandangan buruk mengenai relativisme budaya yang sering disuarakan sama oleh para pendukung universal HAM. Dimana, pendapat pimpinan diberbagai wilayah Asia Tenggara yaitu, Lee Kwan Yew dan Mahathir Mohammad dalam menyuarakan nilai-nilai Asia saat mendalami HAM yang terlihat sama seperti upaya dalam meningkatkan keperluan lain, selain dari HAM. Selain itu daya tarik teori relativisme budaya juga berada pada HAM universal yang pelaksanaanya tetap berlangsung tanpa henti. (Ardani, 2017: 32)

Perbedaan pandangan anatar universal HAM dengan relativisme bdaya sangat berdampak pada munculnya masalah baru salah satunya yaitu mengenai pelaksanaan HAM, tentang 
kewenangan nikah beda agama. Menikah beda keyakinan merupakan pernikahan seorang pria dan wanita yang memiliki keyakinan yang berbeda atau menganut agama yang berbeda, yang bisa juga disebut dengan perkawinan beda agama. Nikah beda agama terjadi sebagai realitas yang tidak bisa dihindari dalam kondisi masyarakat Indonesia yang multikultural ini (Efendi, 2020: 50). Pernikahan beda agama sebenarnya sudah banyak dibahas dan di kaji sama kiyai atau ustazd juga dikaji oleh para intelektual yang berasal dari berbagai daerah. Akan tetapi, permasalahan yang sama terus berulang tanpa adanya penyelesaian, karena itulah kenapa sampai saat sekarang ustazd maupun ilmuan belum bisa sependapat mengenai pernikahan beda keyakinan ini, dimana ada beberapa ustazd maupun kiai membolehkan (hanya antar pria muslim dan wanita Ahli-alkitab) dan ada juga para ulama yang lain tidak membolehkan terjadinya pernikahan beda agama tersebut (Mustafid, 2011: 230). Banyak kasus-kasus yang terjadi tentang pernikahan beda agama antara wanita muslim yang menikah dengan laki-laki non muslim, hal ini bisa kita lihat pernikahan yang pernah terjadi di Indonesia antaranya yaitu, Nurul Arifin (Muslim) menikah dengan Mayong (Katolik), Yuni Shara yang juga menikah dengan Hendri Siahaan dan lain-lainnya. (Efendi, 2020: 50)

\section{METODE PENELITIAN}

Penelitian ini merupakan penelitian kepustakaan. Data yang dikumpulkan berupa data sekunder dengan bahan hukum primernya Undang-Undang Nomor 1 Tahun 1974 tentang Perkawinan.
Bahan hukum sekundernya terdiri dari buku dan jurnal. Memperoleh bahasan dengan cara membaca buku dan jurnaljurnal terkait dan memparafrase hasil bacaan.

\section{UNIVERSALISME HAM DAN RELATIVISME BUDAYA}

Latar belakang kemunculan HAM untuk menjadi sebuah aturan internasional yaitu, memiliki ciri keuniversalan dan kemajuannya dalam gambaran disetiap penerus kuasa yaitu, terjadi pertentangan pemikiran dalam menerapkan HAM yang memiliki cakupan yang cukup luas, antara perspektif universalisme dengan relativisme budaya. Dimana bisa kita lihat mengenai paham universal yang berpandangan bahwasanya budaya "primitif" pasti akan mengalami peningkatan, yang menyebar serta mempunyai cara dalam sebuah aturan juga memiliki kuasa yang sama dengan tradisi atau kebudayaan yang ada di daerah Barat. Sedangkan cultural universalism berpandangan terbalik dengan sbeleumnya, dimana sebuah cultural tidak akan dan tidak bisa diubah sampai kapanpun. (Alston, 2008: 18)

Menurut Satya Arinanto, masalah perdebatan tersebut sebenarnya hanyalah masalah klasik dalam sebuah diskursus mengenai teori HAM. Dalam teori HAM terdapat kecenderungan yang berlaku antara dua buah spektrum yaitu; pertama spektrum ini berdasarkan teori hukum alam di salah satu ujung spektrum. Sedangkan yang kedua, berdasarkan pada teori relativisme budaya di ujung spektrum yang lainnya. Sementara, antara kedua spektrum tersebut terdapat pula 
teori-teori lain yang bertumpu pada sebuah ideologi, baik itu pada kelompok marxis, positivis, agama, maupun ideologis yang lain. Apabila ditelusuri akar sejarahnya, perdebatan tersebut sebenarnya bisa dideteksi sampai periode baru dari kemajuan filsafat. Pada saat zaman Yunani misalnya ada pertikaian pendapat yang sulit antara Socrates dengan kelompok sofis yaitu, Protagoras. Socrates merupakan filusuf yang selalu berjuang menemukan sesuatu yang benar dan yang bersifat universal, namun kelompok sophis tidak, melainkan kebalikan dari Socrates, yang mana ia mengajukan relativisme moral yang akan dijadikan patokan hukum. Ideologi ini berkembang abad ke-18, setelah Johann Gottfried Von Herder menyatakan bahwa setiap wilayah mempunyai ciri khas masing-masing. Suatu kebohongan hanyalah bersifat kewilayahan dan ketaksengajaan (contingent) yang mengakibatkan munculnya nilai universal. (Fathuddin, 2015: 212).

\section{Universalisme HAM}

Universalisme tidak terdiri dari esensi ataupun kodrat manusia yang dikatakakan dimiliki oleh semua orang, melainkan pada pengalaman pembangunan kesamaan dalam keberagaman, konflik, perpecahan dan perjuangan. Universalisme adalah aspirasi, tujuan moral yang harus diperjuangkan (Benhabib, 2017: 17). Universalisme kemudian bertumpu pada universalisme moral yaitu, rasa hormat yang sama terhadap yang lain sebagai makhluk yang mampu dan memiliki kebebasan komunikatif. Akan tetapi, universalisme pembenaran tidak perlu mengendalikan teori yang lengkap tentang sifat manusia atau pandangan dunia moral, religius, atau ilmiah yang lebih komprehensif. (Benhabib, 2017: 13)

Ideologi universal tentang HAM yaitu, universal memposisikan HAM menjadi nilai yang universal seperti yang telah dinyatakan sama dengan beragam gaya International Bills of Human Rights yaitu, caranya dengan tidak memikirkan masalah serta persamaan sosial dan budaya dalam konteks ruang dan waktu yang sudah menempel di berbagai daerah sejak dulunya, disetiap wilayah. Hak asasi manusia di posisikan sebagai ukuran dan aturan yang posisinya melewati kekuasan negara (Jaya, 2017: 57). Pasal 55 Point (c), Piagam PBB menyatakan bahwa penghormatan universal dalam pengakuan kepada HAM yang tidak terikat dalam hal mendasar bagi setiap masyarakat dengan tidak ada lagi perebedaan dalam berbahasa, jenis kelamin, ras ataupun keyakinan (agama). Kemudian dalam Pasal 56 Piagam PBB yang merumuskan tentang seluruh anggota untuk berjanji membuat tindakan bersama-sama ataupun tidak dalam kerjasama dengan kelompok dalam sebuah pencapaian yang dicantumkan dalam Pasal 55. Pasal tersebut mendalilkan bahwa HAM yang bersifat universal serta negara-negara harus mengakui dan juga harus mengambil tindakan terhadap pemenuhan hak-hak tersebut. (Jaya, 2017: 57)

Paham universal memaparkan bahwa HAM tidak memiliki perbedaan dan mesti sama dimana pun dan kapanpun, ketika itu dalam sebuah makna maupun dalam pelaksanaanya. Penganut paham universal juga memaparkan tentang HAM internasional ini dengan unik dan global. Paham ini ditawarkan oleh orang bagian Barat serta 
para Cendekiawan yang datang pada universalisme HAM dengan sebuah penilaian yang tajam oleh reformis Barat (Mustaanu, 2018: 13). Masyarakat tidak setuju dengan berbagai pernyataan tentang cultural relativism dan mengibaratkan hanya sebuah paham yang tidak diterima dan dijadikan untuk merasionalisasikan kesalahan-kesalahan yang terdapat dalam HAM. Kaum intelektual juga berpandangan bahwa HAM merupakan budaya atau tradisi yang dikembangkan oleh orang-orang Barat yang senantiasa menjadi model normatif universal bagi hukum HAM international. (Baderin, 2010: 26)

Istilah Universalisme of Human Rights yang menunjukkan bahwa HAM sebagai sebuah pemikiran yang secara kualitas telah diterima secara mendunia atau global. Namun, tidak dengan pemaknaannya. Oleh karena itu makna Universalisme of Human Rights yang berkaitan dengan penafsiran atau interpretasi dari Human Rights yang juga berkaitan dengan aspek penerapannya yang tidak sekadar terdapat kesamaan antara suatu negara dengan negara lainnya. Sehingga, sampai saat ini belum terdapat atau ditemukan kesamaan ataupun konsensus dari pengertian Human Rights dalam interpretasi dan juga dalam penerapannya. (Ma'aruf, TT: 160)

Muladi Membagi Universal Menjadi dua. Pertama, orang yang berpendapat bahwa universal-absolut akan menilai HAM sebagai sesuatu yang universal seperti yang dinyatakan dalam The International Bill of Human Rights. Orangorang seperti itu tidak bisa menghormati sedikitpun bentuk kehidupan dalam bermasyarakat dan tradisi yang terdapat di setiap wilayah. Pengikut ideologi ini merupakan wilayah-wilayah atau negara yang sudah berkembang. Semua wilayah yang sudah maju sering kali dilihat sebagai pemanfaatan, hal ini disebabkan oleh manusai yang hanya menganggap bahwa mempraktekan HAM hanya sebatas perantara dalam mengendalikan dan hanya sebagai bahan evaluasi (tool of judgment) saja.

Kedua, semua orang yang memiliki pandangan universal dan relatif maka mereka akan melihat HAM sebagai sebuah konflik yang universal, tetapi hal itu juga merupakan pengkhususan yang berlandaskan pada sebuah aturan internasional yang keberadaaannya benarbenar dan sangat dipercaya. (Ma'aruf, t.t: 164)

Berdasarkan paham universalistik, HAM dari sudut pandang univera!ism dilatarbelakangi oleh berbagai alat-alat (instrumen) hukum internasional yang berhubungan dengan hak asasi manusia, pada dasamya manusia memiliki kewenangan atau hak alamiah atau disebut juga dengan hak dasar yang pertama, yaitu HAM yang man terdapatnya hak pada semua orang dalam asasi yang sudah didapat setelah hadir ke dunia ini. Hal ini sangat erat hubungannya dengan keberadaan kehidupan manusia yang bersifat tidak berubah (stagnan) dan utama, serta tidak bisa ditarik, yang juga tidak bergantung baik pada sesuatu ataupun kepada manusia selain dirinya yang ada di sekelilingnya. HAM menjadi asas dari undang-undang diakibatkan oleh cakupan HAM yang cukup besar atau luas. Bentuk dari kewenangan ini yaitu, seperti; adanya hak bebas memilih dalam hidup, kebebasan batin, perkawinan, bebas dalam perkumpulan serta dalam 
mengeluarkan atau mengemukakan pandangan (pendapat), emansipasi kaum hawa dan lain sebagainya.

Ketiga, kewenangan undang-undang (UU), seperti: terdapat hak dalam aturan atau UU yang khususnya diberikan pada pribadi orang. Karena itu, dalam sebuah aturan pasti terdapat di berbagai aturan yang lain yang ada dalam undangundang. Siapapun orangnya ia tidak bisa menutupi segala aturan (hukum) yang terdapat dalam UU, dikarenakan akan dikenakan sanksi terhadapnya, dimana sanki tersebut akan ditentukan oleh orang-orang yang membuat UU tersebut. Sebagai instrumen perundang-undangan hak asasi manusia supaya dipositifkan kaidah-kaidahnya dan disosialisasikan kepada masyarakaat agar masyarakatnya tahu dan juga berusaha dalam menyebarluaskan sarana para pengikut supaya sesuatu yang terdapat dalam hak asasi manusia bisa diikuti dan ditaati. Hal tersebut memiliki implikasi terhadap peraturan undang-undang, sehingga hak asasi manusia bisa berjalan dengan baik dan sesuai aturan, hal ini penting karena ada tindakan dalam penerapan peraturan undang-undang hak asasi manusia dengan benar, disaat melaksanakan perintah bisa berjalan satu arah dan juga berjalan sesuai dengan aturan yang ada, serta penafsirannya yang sudah diterima oleh pendiri hak asasi manusia yang harus meminta orang-orang yang melakukan pelanggaran agar mengikuti atauran yang sudah dibuat. (Syahputra, 2011: 73)

Sejumlah studi serta pembahasan yang dilaksanakan oleh HAM yang mengantarkan kepada berbagai hal yang menimbulkan gugatan tentang ideologi dan nilai-nilai dari universal HAM.
Terdapat beberapa gugatan umum terhadap universalitas HAM, antara lain:

Pertama, nilai universal HAM yang berawal dari pemikiran filosofi dan filosof Barat (western bias) juga dari kepercayaan bahwa setiap manusia memiliki pola pikir dalam bentuk yang berbeda. Kedua, terdapat sejumlah hak yang terdapat dalam Universal Declaration of HumanRights yang pada-dasarnya tidak memenuhi persyaratan untuk "all times". Contohnya yaitu, hak dalam memilih wakil rakyat, hak melaksanakan perkawinan, tentunya tak mungkin bisa diberlakukan kepada setiap usia karena akan menimbulkan masalah baru. Berdasarkan hal itu maka ciri khas universal dinggap tak lagi mencukupi syarat.

Ketiga, ada sejumlah hak terdapat dalam HAM condong berlandaskan pada ide juga tradisi yang bebas dalam bentuk mengabulkan nilai-nilai komunitas yang mungkin saja dimiliki oleh suatu daerah atau negara serta orang-orang khusus. Dalam kata lain, sebuah wilayah atau masyarakat khusus, yang pada dasarya selalu mempunyai kebijakan atau aturan sendiri saat menjaga dan mengakui hak anggotanya. Keempat, beberapa wilayah atau negara di Asia termasuk Indonesia yang memiliki pandangan terhadap universalitas HAM sebagai bentuk agresivitas, hegemoni global, imperialisme budaya, dan peniruan Barat atas berbagai wilayah yang berkembang. (Kunto dan Prajarto, 2005: 294)

\section{Relativisme Budaya}

Keberadaan Masyarakat Hukum Adat (MHA) sejak awal telah memiliki berbagai penafsiran bila dilihat dari berbagai sudut pandang. Ada yang menempatkan MHA sebagai satuan 
masyarakat istimewa karena keterikatannya yang kuat dengan asal usul suatu negara, sehingga MHA perlu diberikan kekhususan seperti nama sendiri; "desa adat, masyarakat hukum adat" yang diatur dalam produk hukum yang menyatakan kekhususannya dalam hal ini ketradisionalannya. Pemahaman tersebut bila ditelusuri akan berakar pada doktrin cultural relativism. (Al-Khanif, Wiratman, 2017: 348)

Relativitas budaya adalah fakta budaya berbeda, seringkali secara dramatis melintasi ruang dan waktu. Relativisme budaya adalah seperangkat doktrin yang mengilhami relativitas budaya dengan kekuatan preskriptif (Donelly, 2006: 16). Relativisme budaya juga diartikan sebagai sebuah ideologi yang sedikit banyaknya dipaksakan akibat dari keberagaman budaya yang terdapat di berbagi wilayah, selalu ada keadaan dimana orang-orang yang memiliki kuasa tidak setuju, pada saat ada suatu pengikutnya menolak hak pengikut lainnya, maka hal ini tak jarang terjadi untuk keperluan pengikut atau kelompok itu sendiri. Oleh sebab itu HAM tak bisa secara penuh memiliki sifat universal kecuali ketika HAM tak lagi mengikuti aturan suatu budaya yang tak jarang dibentuk dengan tidak menggunakan suara bulat, dan dengan begitu maka tidak bisa mewakili semua orang. (Afif, 2017: 32)

Masalah relativisme budaya (cultural relativism) datang ketika perang dingin akan berakhir sebagai jawaban kepada pernyataan universal dari gagasan hak asasi manusia internasional. Yaitu, Gagasan mengenai cultural realitivism yang menyatakan kebudayaan adalah satu-satunya sumber keabsahan hak atau kaidah moral. Inilah kenapa HAM sangat penting untuk dimengerti di masingmasing dalam tradisi suatu wilayah atau negara. Setiap kebudayaan memiliki hak untuk hidup dan memiliki kesamaan martabat dan yang wajib untuk dihargai. Berdasarkan pernyataan ini, orang-orang yang mendukung gagasan relativisme budaya tidak menerima universalisasi HAM, ketika dicampuri oleh suatu tradisi. (Alston, 2008: 20).

Persepsi ini yang akhirnya menyebar luas pada abad ke-18 setelah Johann Gottfried Von Herder menegaskan bahwasanya setiap bangsa mempunyai ciri khas masing-masing yang memiliki dampak pada nilai universal yang menjadikan suatu hal yang dusta, dan hanya bersifat kewilayahan serta tidak disengaja (contingent). Relativisme menegaskan bahwa perlindungan hak asasi manusia yang universal merupakan bentuk dari sebuah intervensi budaya (cultural imperialism) dari suatu bangsa Barat. Universalisme tersebut telah merusak keberagaman tradisi serta bentuk hegemonisasi budaya (cultural hegemonisation) dalam menuju suatu dunia modern.

Menurut Howard, relativisme budaya adalah konsepsi absolutisme budaya yang menjelaskan bahwa suatu budaya dalam masyarakat merupakan nilai etis yang tertinggi. HAM tidak bisa lagi didukung ketika penerapannya mengakibatkan perubahan pada suatu tradisi tersebut, maka dalam pelaksanaan HAM tersebut harus disesuaikan dengan budaya di masing-masing negara. Asosiasi Antropologi Amerika (American Anthropologial Association) mengeluarkan suatu pernyataan di depan Komisi HAM PBB pada saat Komisi ini sedang 
mempersiapkan rancangan Deklarasi Universal HAM yang menginginkan pentingnya untuk dipikirkan, dalam penyusunan suatu deklarasi, agar bisa menyelesaikan problem-problem seperti, cara deklarasi kelak bisa berperan bagi semua masyarakat serta bukan sebuah gagasan tentang hak-hak (statement of rights) yang hanya sekedar mendeskripsikan nilai-nilai lazim yang ditemukan di setiap negara Eropa Barat dan juga di Amerika. (Jaya, 2017: 59)

Pemahaman yang diajarkan dalam relativisme budaya ini adalah bahwa budaya merupakan satu-satunya keabsahan hak atau kaidah moral, sehingga hak asasi manusia harus dipahami dari konteks kebudayaan dari tiap-tiap negara. Relativisme budaya menempatkan nilai-nilai kebudayaan, adat, kearifan lokal sebagai suatu yang sakral tanpa kehilangan fungsi aplikatifnya dalam masyarakat sehingga keberadaannya harus dipertahankan dari satu generasi ke generasi selanjutnya. Sedangkan implikasi dari MHA dalam pemahaman relativisme budaya akan ditempatkan sebagai etnitas sakral pula, yang dalam konteks regulasinya sangat mungkin untuk dijadikan objek yang lepas dari kuasa MHA itu sendiri, misalnya dijadikan sebagai objek wisata, dan lain sebagainya. (Wiratman, 2017: 348)

Teori relativisme budaya disarankan oleh beberapa negara-negara yang bukan orang Barat serta cendikiawan yang menyatakan bahwa hak asasi manusia tidak saja bertumpu pada tradisi Barat, melainkan melekat dalam sifat masyarakat serta berdasarkan moralitas. Dengan hal demikian menenai hak asasi manusia, mereka berpendapat bahwa hal tersebut tidak dapat ditafsirkan jika tidak memperhatikan perbedaan suatu budaya dan masyarakatnya. (Mustaanu, 2018: 13)

Beberapa dari relativisme memiliki persepsi yang tidak berbeda mengenai hak asasi manusia internasional. Ada beberapa yang menerima tetapi juga ada yang menolak universalisme tersebut, selama teori itu tidak mengganggu ataupun merusak kepercayaan poin penting (inti) dari tradisi mereka. Karena itulah mengapa pentingnya dibicarakan dari sebagian bentuk relativisme dalam sebuah tradisi.

Jack Donnelly membagi relativisme budaya menjadi tiga kategori. Pertama, pengikut "relativisme budaya radikal" yang menyatakan bahwa budaya merupakan satu-satunya sumber kebenaran dan moral atau sebuah kebijakan-kebijakan hukum lainnya. Pandangan ini berdampak pada lahirnya fundamentalisme yang tidak menerima nilai-nilai yang muncul bukan dari mereka. Dalam cakupan sebuah tradisi, pandangan tersebut dapat memunculkan pemikiran-pemikiran yang menjunjung tinggi budayanya dan menganggap remeh budaya orang lain atau disebut juga 'cauvinisme.' Akan tetapi, dalam konteks keyakinan, pemikiran seperti itu akan memunculkan paham radikalisme dan fundamentalisme agama yang tidak menerima sebuah kebenaran agama dalam keyakinan lain. Pengikut relativisme radikal ini menilai bahwa suatu budaya, tradisi atau agama mereka mengandung nilai-nilai tinggi yang tak akan dapat digantikan dengan nilai-nilai manapun. Maka dari itu, ideologi tersebut tidak menerima atau menolak setiap norma-norma yang brasal dari luar mereka serta diduga dapat merusak nilai 
inti dari sebuah agama tersebut. Dalam konteks HAM, tentu relativisme radikal ini tidak akan menerima keuniversalan hak asasi manusia. Hal ini karena banyak alasan yang menjadi dasar pendapat ini. Contohnya, seperti mereka mencurigai adanya ide lain yang berdiri dibelakang hak asasi manusia misalnya, westernisasi atau orientalisme dalam melemahkan ideologi pengikut relativisme. Bahkan, ada yang berpandangan bahwa mereka tidak lagi harus menerapkan hak asasi manusia internasional karena ideologi yang mereka miliki telah tercukupi dalam menjamin hak tersebut.

Kedua, relativisme budaya mempunyai penganut yang kuat, mereka memiliki anggapan bahwa budaya merupakan sumber primer dari sebuah kebenaran yang berasal dari sebuah aturan atau hak. Sedangkan waktu yang bersamaan, pengikut paham ini beberapa hak-hak dasar manusia yang asalnya dari luar. Dalam cakupan agama, pandangan ini dapat menerima norma-norma yang tidak menentang budaya inti dari agama tersebut yang merupakan keyakinan. Pertentangan terhadap kepercayaan itu mungkin dapat menghilangkan nilai-nilai yang bersih dari agama atau keyakinan. Sementara dalam konteks budaya, perlawanan kepada budaya inti yang mungkin dapat mengubah struktur masyarakat. Misalnya, halnya kesetaraan gender yang disebarluaskan oleh konvensi mengenai setiap bentuk penindasan kepada kaum wanita yang dianggap menyerang hegemoni laki-laki kepada para wanita yang terdapat didalam sebagian ajaran agama dan budaya tertentu. Salah satunya diantara kesetaraan gender yang ditentang yaitu, mengenai larangan terhadap praktek poligami dalam sebuah pernikahan.

Ketiga, pengikut 'relativisme budaya lemah' pendukung ini beranggapan bahwa budaya merupakan sumber kebenaran yang kedua atas hak dan norma-norma. Ideologi ini dinamakan sebagai pandangan yang liberal karena pengikut teori ini dapat menerima setiap bentuk nilai yang berasal dari luar selagi nilai-nilai tersebut dianggap positif. Pengikut paham ini tak hanya menghapus identitas lamanya karena mereka masih menerapkan nilai-nilai baik yang muncul dari budaya tersebut. Melainkan sebaliknya, pada saat nilai tersebut tampak berisi tentang unsur-unsur yang bersifat sektarian dan primordial, karenanya paham ini dapat mengadopsi nilai-nilai yang bukan dari bentukan mereka melainkan dari luar yang dijadikan sebagai penyempurna nilai-nilai dari budaya mereka. (Al-khanif, 2016: 41)

Relativisme budaya terasa sulit dikritik disebabkan paham ini dianggap mempercayai tidak adanya ide, nilai, budaya, dan juga praktek-praktek yang positif maupun negatif. Jadi maksudnya adalah mengenai perbuatan manusia dalam kerangka kebudayaan. Mereka tidak dapat menganggap positif ataupun negatif karena paham ini terletak dalam logika budaya mereka sendiri. Dimensi yang sesuai dari relativisme budaya ini menjadi bidang penghalang untuk menetralisir nilai dari logika budaya yang lain, juga termasuk nilai dan moralitas dari HAM hal itu karena keduanya memiliki latar belakang yang berbeda. (Wagiman, 2012: 32)

Kata kunci yang perlu untuk digunakan dan dicermati yaitu, bahwa relativisme budaya bukan suatu posisi 
teoretik yang sudah selesai, tetapi merupakan sebuah usaha untuk mengerti sebuah perbuatan serta kepercayaan dalam budaya lain menurut pandangan budaya, materi, dan sejarahnya. Hal Ini bukanlah sebuah terminologi hak yang penting untuk diterima dalam konteks budaya tertentu yang seolah-olah tidak ditemukan prinsip umum mengenai hak itu sendiri. Tetapi malah sebaliknya, prinsip yang lumrah tentang hak itu dapat keluarkan, setidaknya untuk dua alasan: pertama, untuk usaha dalam membela masyarakat dari masalah serta tidak mengikuti aturan yang dilakukan oleh suatu negara ataupun pihak lain. Kedua, hak yaitu, justifikasi perlindungan kelompok atau perorangan dalam masyarakat, walaupun mereka tidak mengetahui adanya hak itu sendiri. (Wagiman, 2012: 33)

\section{FENOMENA PERNIKAHAN BEDA AGAMA DI INDONESIA}

Masalah pernikahan beda agama masih menjadi kontroversi. Untuk melakukan pernikahan beda agama dalam masyarakat masih terasa agak sulit, sedangkan pernikahan beda agama itu sendiri merupakan realitas yang tetap terjadi. Pernikahan antara laki-laki dan perempuan yang memiliki keyakinan tidak sama, biasanya salah satu dari mereka harus masuk ke kepercayaan lain. Baik itu dari agama semu maupun agama yang sebenarnya. Seperti, ada seseorang berkeyakinan katolik yang ingin menikah dengan yang beragama selain katolik, dengan sakramen gereja Katolik maka harus meraih keringanan dulu dari keuskupan wilayahnya, keringanan ini diberikan setelah mengikuti pelatihan agama katolik satu tahun. Dengan adanya keringanan itu maka keduanya bisa menikah secara agama Katolik. Tetapi status agamanya dari non-Katolik tersebut belum sepenuhnya menjadi umat Katolik, melainkan baru sebagai penundukan terhadap hukum agama Katolik. (Wahyuni, 2010: 72)

Sedangkan seseorang yang beragama Budha ingin melakukan pernikahan dengan orang yang beragama non-Budha, maka orang non-Budha masuk ke agama Budha dengan cara mengganti status di Kartu Tanda Penduduk (KTP), begitu juga dengan penganut Hindu dengan Non-Hindu, orang yang beragama Kristen dengan Non-Kristen. Solusi yang paling mudah dalam melakukan pernikahan beda agama dengan cara masuk agama semu dan menukar agama di KTP. Hal ini berbeda dengan agama Islam dan Katolik karena masuk ke dalam agama semu itu tidak mudah. Tetapi bagi orang kaya, melangsungkan pernikahan beda agama bisa dilakukan di luar negeri agar terhindar dari sulitnya prosedur dan perlangsungan pernikahan beda agama di Indonesia, tetapi dilihat dari sisi lainnya pernikahan beda keyakinan bagaimanapun tidak bisa dihindarkan lagi dalam kenyataan hidup masyarakat yang multikultural. (Wahyuni, 2010: 73)

Pernikahan beda agama sudah menjadi sesuatu yang biasa atau lumrah dalam kehidupan sosial masyarakat (Humbertus, 2019: 106). Sehingga, terjadi perbedaan agama baik sebelum pernikahan ataupun sesudah pernikahan. Sedangkan perbedaan agama ini bisa menimbulkan masalah dalam menuju pernikahan. Undang-Undang Pernikahan dengan lantang menolak untuk 
melangsungkan pernikahan bagi orang yang memiliki beda agama. Karena sebuah pernikahan akan dia anggap sah jika sang mempelai patuh atau ikut dengan aturan bahwa tidak ada larangan atas sebuah pernikahan dalam agamanya. Hal ini menyebabkan timbulnya berbagai penafsiran. (Arifin, TT: 151)

\section{Pernikahan Beda Agama sebagai HAM}

Pernikahan beda agama adalah permasalahan yang sampai sekarang masih belum menemukan titik penyelesaian di dalam kehidupan sosial masyarakat. Undang-Undang perkawinan memiliki peran dalam menentukan sah atau tidaknya sebuah pernikahan dalam hukum agama dan keyakinan antara mempelai laki-laki dan mempelai perempuan tersebut. Hal ini bisa dilihat pada pasal 2 Undang-Undang Perkawinan yang menjelaskan bahwa pernikahan harus mentaati dan dilarang melanggar ajaran kitab suci, dimana pernikahan yang akan sah menurut negara yaitu, yang tidak melanggar apa yang diajarkan agama. (Humbertus, 2019: 106)

\section{Pernikahan Menurut Hukum Nasional}

Sejak Indonesia merdeka yang diproklamirkan pada tanggal 17 Agustus 1945 sampai pada era sekarang regulasi pernikahan di Indonesia telah diatur dalam beberapa peraturan perundang undangan: a). Buku I KUHPer, b). Undang-undang No. 1 tahun 1974 tentang Perkawinan. c). Undang-undang No. 7 tahun 1989 tentang Peradilan Agama, d). Peraturan Pemerintah No. 9 tahun 1975 mengenai Peraturan Pelaksanaan UU No.1 tahun 1974, dan e). Instruksi
Presiden No.1 Tahun 1991 tentang Kompilasi Hukum Islam Indonesia. (Arsal, 2013: 40)

\section{Pengaturan Pernikahan Era 1945 s/d 1974}

Era 1945 merupakan mumentum negara Indonesia mendapatkan hak kemerdekaan secara penuh dan terlepas dari cengkraman penjajah. Dalam aspek hukum masih terlihat keragaman peraturan perundang-undangan yang berlaku. Hal ini sebagai cerminan dari bentuk pluralitas masyarakat Indonesia tersebut. Di antara bentuk keragaman itu terlihat pada ketentuan hukum pernikahan yang diberlakukan di masa ini sebagai berikut: 1. Bagi orang Indonesia Asli yang beragama Islam berlaku hukum agama yang telah diresipiir dalam hukum adat. 2. Bagi orang Indonesia Asli lainnya berlaku Hukum Adat. 3. Bagi orang-orang Indonesia Asli yang beragama Kristen berlaku Huwelijks Ordonnantie Christen Indonesia (S. 1933 Nomor 74). 4. Bagi orang Timur Asing Cina dan warganegara Indonesia keturunan Cina berlaku ketentuan-ketentuan Kitab UndangUndang Hukum Perdata dengan sedikit perubahan. 5. Bagi orang-orang Timur Asing lain-lainnya dan warganegara Indonesia keturunan Timur Asing lainnya tersebut berlaku hukum Adat mereka. 6 . Bagi orang-orang Eropa dan Warganegara Indonesia keturunan Eropa dan yang disamakan dengan mereka berlaku Kitab Undang-Undang Hukum Perdata. (Arsal, 2013: 40)

\section{Pengaturan Pernikahan di Era 1974 - Sekarang}

Kemajuan yang sangat berarti bagi bangsa Indonesia, terutama bagi umat Islam adalah diundangkannya regulasi 
mengenai pernikahan, sehingga dalam hal pernikahan bangsa Indonesia telah mempunyai satu pedoman dalam hal melangsungkan pernikahan, yakni Undang-undang Nomor 1 Tahun 1974. Kehadiran UU no.1 tahun 1974 tidaklah mudah, akan tetapi melalui perjalan panjang yang melelahkan dan ditambah dengan dinamika pendapat yang kotroversial. (Arsal, 2013: 42)

Berlakunya Undang-Undang No. 1 Tahun 1974 mengenai pernikahan, yang mengatur tentang undang-undang perkawinan Hindia Belanda yang sudah disahkan bahwa tidak lagi berlaku. Hal ini dinyatakan secara tegas dalam Pasal 66 UU Perkawinan. Dalam pasal ini ditetapkan persyaratan untuk melakukan pernikahan, diantaranya adalah adanya unsur kerelaan antara kedua calon mempelai tanpa ada rasa terpaksa. Serta harus memiliki usia 21 tahun, jika belum berusia dewasa maka harus mendapat izin orang tua ataupun walinya. (Arsal, 2013: 44)

Undang-Undang No.1 Tahun 1974 ini mengarah ke hukum agama. Hukum peraturan undang-undang ini secara umum mengatur mengenai pernikahan dan juga pernikahan beda agama di Indonesia. Jika kita membaca UU perkawinan maka akan banyak terlihat pasal mengenai hukum agama. Semua agama pada dasarnya menganjurkan umatnya untuk memiliki pasangan seagama. Agar tidak susah dalam menetapkan keyakinan anak kelak. Perkawinan merupakan sesuatu yang dianjurkan oleh agama. Karena sudah menjadi kebutuhan dalam konsep Islam yaitu agar menjaga keturunan dengan cara pernikahan serta kewajiban menafkahi keluarga. Dapat kita lihat bahwa agama mendukung umatnya untuk menikah dan menjaga keturunannya. Sedangkan pernikahan pada hukum agama dibuktikan dengan pasal 2 ayat 1 UU No 1 tahun 1974, bahwa pernikahan sah jika dialakukan sesuai hukum agama masing-masing. Dalam pasal ini, terlihat bahwa semua pernikahan selalu berada dalam hukum agama. Semua perkawinan harus sesuai dengan hukum agama selama tidak bertentangan dengan UU perkawinan. Maka tertutup kemungkinan diakui bagi orang yang nikah beda agama dalam negara dan agama. (Humbertus, 2019: 106)

Mencermati sekilas pasal-pasal tentang larangan nikah, ternyata UU No. 1 tahun 1974 belum memasukkan unsur beda agama secara eksplisit sebagai salah satu point yang dilarang itu kawin. Namun demikian, secara implisit sebenarnya dalam undang-undang ini telah terkandung adanya larangan perkawinan beda agama. Barangkali tidak disebutnya secara eksplisit larangan kawin beda agama menyadari akan keragaman dan untuk memelihara persatuan dan kesatuan bangsa. Kemudian setahun setelah itu pemerintah mengeluarkan PP (Peraturan Pemerintah) No 9 tahun 1975 tentang pelaksanaan UU No 1 tahun 1974. Dengan keluarnya PP maka undang-undang tentang pernikahan telah berlaku secara efektif. (Arsal, 2013: 44)

Dalam sistem hukum Indonesia, pernikahan antar agama dapat terjadi. Hal ini disebabkan peraturan perundangundangan tentang pernikahan memberikan peluang tersebut terjadi, karena dalam peraturan tersebut dapat memberikan beberapa penafsiran bila 
terjadi pernikahan antar agama. (Arsal, $2013: 45)$.

Sedangkan larangan pernikahan dalam UU Pernikahan pasal 8 berisikan hanya melarang pernikahan jika keduanya ada hubungan khusus seperti sedarah, semenda serta seperti hubungan yang emang sudah dilarang dalam agama atau aturan lainnya. (Arsal, 2013: 44) Indonesia merupakan sebuah negara hukum, yang berarti Indonesia berlandaskan hidupnya ke sebuah aturan hukum, tidak kepada ajaran sebuah agama. Akibat dari kedua pasal di atas maka muncullah perbedaan terhadap hubungan antara beda agama yang ingin melangsungkan pernikahan. Karena jika mereka melakukan pernikahan maka salah satu dari mereka harus merelakan agamanya dan mengikuti agama dari salah satu pasangannya. Bisa kita simpulkan bahwa mengenai kebebasan beragama dan berkeyakinan telah dilanggar oleh UU tersebut. (Humbertus, 2019: 106)

Dalam pasal 57 Undang-Undang Perkawinan dijelaskna bahwa sah serta boleh dilangsungkan sebuah pernikahan pernikahan campuran, yaitu dimana dua orang yang mengikuti hukum yang berlainan. Bahkan, pasal ini tidak hanya mengatur tentang perkawinan beda kewarganegaraan tetapi juga mengatur tentang pernikahan beda agama. Pelaksanaan pernikahan dilakukan berdasarakan aturan yang terdapat dalam pasal 6 PPC yaitu, bahwa pernikahan campur hanya berlaku untuk suami, kecuali tidak ada izin dari kedua belah pihak sang mempelai yang merujuk pada pasal 66 Undang-Undang Pernikahan. (Amri, 2020: 59)

\section{PERNIKAHAN BEDA AGAMA DALAM KONTEKS UNIVERSALISME HAM DAN RELATIVISME BUDAYA}

Pernikahan beda agama merupakan sebuah pernikahan yang dilaksanakan oleh dua orang manusia yang memiliki keyakinan yang berbeda serta diikat dalam satu ikatan pernikahan (Arifin, t.t: 145). Universalitas memiliki pandangan bahwa hak asasi manusia adalah hak yang dimiliki oleh semua manusia di setiap saat serta tempat atas awal keberadaannya sebagai seorang manusia. Semua manusia memiliki hak dalam kepemilikian dan penghormatan atas hak asasi manusia (Matondang, 2008: 207). Pandangan universalitas terhadap pernikahan beda agama terdapat dalam pasal-pasal Deklarasi Universal Hak Asasi Manusia yaitu, hak kebebasan kawin (pasal 16 UDHR) yaitu hak kawin beda agama dan hak bebas memilih kepercayaan (agama) masing-masing (pasal 18 UDHR) yang merupakan hak mengganti atau pindah kepercayaan. Keputusan Deklarasi Universal Hak Asasi Manusia ini diterima penuh oleh negara Tunisia dan Pakistan. Negara Barat memiliki tataran dalam perumusan hak asasi manusia, misalnya dalam hak kebebasan beragama dan dibebaskan untuk kawin. (Matondang, 2008: 211)

Sedangkan pandangan teori relativitas budaya yaitu, manusia adalah produk dari kehidupan sosial budaya. Memiliki tradisi budaya dalam masyarakat juga berakibat pada pemikiran dan pandangan mengenai manusia, juga termasuk dalam hal hak asasi manusia. Budaya (cultural relativism) bertentangan dengan adanya perspektif mengenai hak yang bersifat universal. HAM harus diletakkan pada konteks 
budaya tertentu di setiap masing-masing negara. Karena kebudayaan adalah menjadi satu-satunya sumber dari keabsahan hak atau kaidah moral. Setiap kebudayaan mempunyai hak untuk hidup dan martabat yang sama serta wajib untuk dihargai, maka dari itu dalam menerapkan HAM harus tetap mempertimbangkan karakteristik, perbedaan sejarah, budaya, dan agama di masing-masing negara.

Menerapkan dan melakasanakan HAM di Indonesia harus sesuai dengan nilai-nilai dan budaya yang berlaku di Indonesia "relativisme budaya". Sebagai penghormatan atas negara Indonesia di berbagai konvensi juga perangkat hukum internasional juga termasuk hak asasi manusia haruslah sesuai dan berdasarkan pada sejarah, falsafah, budaya dan konstitusi Negara Kesatuan Republik Indonesia. Contohnya dalam menerapkan kebebasan berkeyakinan, beragama dan perkawinan. (Jaya, 2017: 64)

\section{KESIMPULAN}

Terdapat pandangan/ide yang berseberangan terhadap konsep HAM khususnya tentang perkawinan beda agama, yaitu pandangan universalisme (universalism) dan relativisme budaya (cultural relativism). Universalisme memposisikan HAM sebagai nilai-nilai universal seperti yang terdapat dalam segala jenis International Bills of Human Rights yang menyatakan bahwa HAM secara alami yang dimiliki oleh orang pribadi. Pandangan universalitas terhadap pernikahan beda agama terdapat dalam pasal-pasal Deklarasi Universal Hak Asasi Manusia yaitu, hak kebebasan kawin (pasal 16 UDHR) yang meliputi hak kawin antar pemeluk agama (beda agama) dan hak kebebasan beragama (pasal 18 UDHR) yang meliputi hak berpindah agama.

Sedangkan relativisme budaya berpandangan (cultural relativism), bahwa kebudayaan merupakan satu-satunya sumber keabsahan hak atau kaidah moral. Semua kebudayaan mempunyai hak untuk melangsungkan kehidupan serta kedudukan yang tidak berbeda dan wajib untuk dihargai, dengan demikian HAM harus berada dalam konteks budaya tertentu di masing masing negara. Dengan dalil tersebut relativisme budaya menyatakan bahwa "there is no such thing as universal rights" yang merupakan suatu penolakan terhadap persepsi adanya hak yang bersifat universal apalagi bila hak tersebut didominasi oleh suatu budaya tertentu. Karena itulah penerapan hak asasi manusia harus sesuai dengan sejarah, budaya dan lainnya, begitu juga dengan penerapan hak kebebasan perkawinan agar disesuaikan dengan kondisi sosial budaya. Maka dari itu antara universalisme HAM dengan Relativisme Budaya sama-sama memberikan hak masing-masing terhadap masyarakat yang ingin menikah baik antar keyakinan maupun tidak, karena itu termasuk dalam hak pribadi, selagi tidak melanggar aturan dalam agama masingmasing.

\section{DAFTAR PUSTAKA}

A, M. B. (2010). Internasional Human Rights and Islamic Law. Jakarta: Komisi Nasional Hak Asasi Manusia.

Afif, N. A, Dkk (2017) Relativisme Budaya Dalam Hak Asasi Manusia. Jurnal Cakrawala Hukum, 32. 
Al-Khanif, H. P. W. (2017). Hak Asasi Manusia: Dialektika Universalisme Vs Relativisme di Indonesia. Yogyakarta: LkiS.

Al-Khanif. (2016). Diktat Mata Kuliah Hak Asasi Manusia, Jember: Fakultas Hukum Universitas Jember.

Alston, P. (2008). Hukum Hak Asasi Manusia. Yogyakarta: Pusat Studi Hak Asasi Manusia Universitas Islam Indonesia (PUSHAM UII).

Amri, A. (2020). Perkawinan Beda Agama Menurut Hukum Positif dan Hukum Islam. Media Syariah. 22(1), 59.

Arsal. (2013). Pengaturan Perkawinan Beda Agama di Indonesia (Kajian Sejarah Sosial Hukum Islam Era 1945-Sekarang). Al-Hurriyah, 14(1), 44.

Baderin, M. A. (2010). penerjemah Internasional Human Rights and Islamic Law, Musa Kazhim dan Edwin Arifin, Jakarta: Komisi Nasional Hak Asasi Manusia

Benhabib, S. (2007). Universalism: On the Unity and Diversity of Human Rights, American Philosophical Association. Vol. 81(2): 13-17.

Donnelly, J. (2006). The Relative Universality of Human Right (Revised), Human Right \& Human Welfare. 33 (16).

Efendi, R. (2020). Perkawinan Beda Agama dalam Paradigma Sosiological Jurisprudence, AlHurriyah, 5 (1), 50.

Fathuddin. (2015). Kebebasan Beragama Dalam Bingikai Otoritas Negara (Religious Freedom In The Frame
Of State Authority. Jurnal Legilasi Indonesia. 12(2), 212.

Humbertus, P. (2019). Fenomena Perkawinan Beda Agama Ditinjau dari UU 1 Tahun 1974 Tentang Perkawinan. Law and Justice. 4(2), 106.

Khoirul, M. F. (2018). Dinamika Universalitas Dan Relativisme Dalam Hak Asasi Manusia. Jurnal Komunikasi Dan Penyiaran Islam.

Kunto, K. Y. N. P. (2005). Hak Asasi Manusia (HAM) Di Indonesia: Menuju Democratic Goaernances, Jurnal Ilmu Sosial Ilmu Politik. TvTn, 294.

Ma'ruf, U. (t.t). Otonomi Keilmuan Dan Pemaknaan Hak Asasi Manusia Yang Universalis Atau Partikularis. Jurnal Hukum, XVIII (8), 160-164.

Matondang, I. (2008). "Universalitas dan Relativitas Ham." Miqot. XXXII (2), 205-211.

Mega, B. J. M. R. A. (2017). Universalism Vs. Cultural Relativism dan Implementasinya dalam Hak Kebebasan Beragama Di Indonesia. Jurnal Pena Justisia: Media Komunikasi dan Kajian Hukum.

Mustaanu, A. (2018). Dialektika Komunikatif Antara Ham Internasional Dan Hukum Islam, Journal of Islamic Communication, 13.

Mustafid, F. (t.t). Perkawinan Beda Agama dan Kebebasan Individual Manusia dalam Islam: Perspektif "Teori Naskah" Mahmoud Thaha. Musawa. 10(2): 230.

Syahputra, A. (2011). Kontroversi Hak Asasi Manusia Antara Universal 
dan Partikular, Jurnal Keadilan Progresif, 73.

Wagiman, W. Dkk. (2012). HAM sebagai Bahasa Perdamaian Sebuah Perkenalan Awal dengan Kaum Muda. Jakarta Selatan: ELSAM, Lembaga Studi dan Advokasi Masyarakat.

Wahyuni, S. (2010). Kontroversi Perkawinan Beda Aagama di Indonesia. Hukum Islam. 8(1), 72-73. 